Potravinarstvo Slovak Journal of Food Sciences

vol. 15, 2021, p. 513-520

https://doi.org/10.5219/1527

Received: 15 December 2020. Accepted: 7 June 2021.

Available online: 28 June 2021 at www.potravinarstvo.com

(C) 2021 Potravinarstvo Slovak Journal of Food Sciences, License: CC BY 4.0

ISSN 1337-0960 (online)

\title{
ASPECTS OF THE INFLUENCE OF VEGETABLE-OIL-BASED MARINADE ON ORGANOLEPTIC AND PHYSICOCHEMICAL INDICATORS OF THE QUALITY OF SEMI-FINISHED NATURAL MARINATED MEAT PRODUCTS
}

\author{
Oksana Shtonda, Kateryna Semeniuk
}

\begin{abstract}
This work evidences the expediency of marinade application based on blends of refined vegetable oils in the technology of natural marinated semi-finished meat products. Formulations of natural marinated semi-finished meat products using blends of refined vegetable oils (rapeseed, olive, and sunflower) enriched with the enzyme bromelain were developed in this work. Such formulations can provide the human body with the necessary amount of protein, released by enzymatic hydrolysis of the connective tissue proteins collagen and elastin catalyzed by the plant-based enzyme bromelain, as well as the necessary $\omega-3$ and $\omega-6$ polyunsaturated fatty acids, which are not synthesized in the human body but sourced from food and are one of the main structural units for many vital processes. The article presents the results of a study of organoleptic and physicochemical parameters of natural marinated semi-finished meat products from beef and pork. It is confirmed that the use of rapeseed oil and rapeseed:sunflower oil blend in a ratio of 70:30 produce the best organoleptic characteristics in both semi-finished beef and semi-finished pork: a tender, juicy texture, a pleasant taste and aroma, and an attractive appearance. It has been proven that the use of marinades based on blends of refined vegetable oils reduces the free moisture content and moisture-retaining capacity of the product, due to the presence of refined vegetable oils in the marinade, which contributes to the binding of moisture. The use of marinades based on refined vegetable oils can increase product yield. Vegetable oil, when used in meat marinade, mitigates the ill effects of acid inclusion. It dissolves well the aromas of added spices, and as it seeps through the structure of the meat, the oil gently envelops it, sealing in moisture and preventing drying out during cooking.
\end{abstract}

Keywords: natural marinated semi-finished meat products; blends; vegetable oils; organoleptic parameters; physicochemical parameters

\section{INTRODUCTION}

Improving the technology of natural marinated meat products is a very important issue because the pace of human life changes very quickly and increases every day. This leads to a deterioration of the diet, which in turn is harmful to human health.

Moreover, due to the insufficient quantity of raw meat produced in Ukraine, there is a need to create food that will have a higher yield and provide the human body with the necessary amount of protein and micronutrients (Sukhenko et al., 2017). Therefore, it is necessary to create products that can be cooked rapidly, without losing their biological and nutritional value (Koh, 2005).

For that reason, it is necessary to use meat with a high content of connective tissue for the production of marinated semi-finished meat products, as it is less expensive than traditional raw materials used for semi-finished products. In this manner, the cost of the product can be reduced.

Thus, there is an urgent need for meat products of high nutritional and biological value, which are balanced in fatty acid composition and rapid to cook. Once this problem is solved, the range of natural marinated meat products can also be expanded (Mushtruk et al., 2020b).

Scientists from all over the world are turning their attention to creating products that are quick to prepare and have a positive effect on the human body without losing their biological and nutritional value. In particular, the following domestic and foreign scientists are working in this area of research: L. Vinnikova, V. Yevlash, L. Caprelyants, M. Klimenko, I. Radzievska, A. Belinska, B. Pasichny, G. Simakhina, N. Tkachenko, A. Nechaeva, L. Diaz, W. Schnackel, F. Jemenez-Colmenero, I. Yilmaz, T. Dzudie and others (Kolyanovska et al., 2019). However, there is a need to continue research in this area, namely on the ingredients that increase the biological and nutritional value of products, as well as the effect of these ingredients on finished products, in particular the effect of blends of refined vegetable oils enriched with bromelain on the properties of natural marinated semi-finished meat products (Mushtruk et al., 2020a). 
Vegetable oils are an important component of the diet. It has been shown that reducing the proportion of fat in the diet from $37 \%$ to $30 \%$ of total calories can prevent approximately $2 \%$ of deaths from cardiovascular disease among people over 65 years of age. Nevertheless, avoiding total fat is not the best strategy for the human body. The best option is to balance the consumption of unsaturated (oils) and saturated fats. This can be achieved by introducing unsaturated fats into the product, balanced in fatty acid composition. In nature, oils with a balanced fatty acid composition do not exist, which raises the question of mixing (blending) (Tyshchenko et al., 2019; Belinskaya, 2011).

World Health Organization (WHO) statistics show that $15 \%-30 \%$ of the total energy required for the normal functioning of the human body should come from the consumption of dietary fats: $10 \%$ from saturated fatty acids, $6 \%-10 \%$ from polyunsaturated fatty acids $(5 \%-8 \% \omega-6$, $1 \%-2 \% \omega-3), 10 \%-15 \%$ from monounsaturated fatty acids and less than $1 \%$ from the consumption of transisomers of fatty acids. Scientists have proved that the most useful for the human body are two-chain polyunsaturated fatty acids, which are not synthesized in the body but can only be sourced from food. Especially important is the $\omega$ -

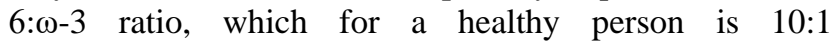
(Domaretskyy and Ostapchuk, 2003; Gubsky, 2000).

Many studies have confirmed the important role of a balanced ratio of $\omega-6: \omega-3$ fatty acids, which are involved in many biochemical processes in the human body, which reduces the risk of serious diseases, especially cardiovascular disease, cancer, osteoporosis, diabetes, and others. The amount of polyunsaturated fatty acids is greater in vegetable oils than in products of animal origin, so the inclusion of these products in the diet is necessary (Brenna, 2002; Proust, Lucas and Deawailly, 2014; Tvrzická et al., 2009).

The creation of blends from different types of oils is already very popular in Europe, but the culture of consumption of such products is not yet sufficiently formed among Ukrainians. Nevertheless, products of this type are already appearing on the shelves of Ukrainian stores (Sukhenko et al., 2020). The diet of Ukrainians is dominated by oils containing fatty acids of the $\omega-6$ family, mostly sunflower oil, and almost excludes products rich in acids of the $\omega$-3 family, such as flaxseed, rapeseed, pumpkin and walnut oils. However, to increase the biological and physiological value of oils by regulating the $\omega-6: \omega-3$ ratio within the PUFA content, oils can be mixed or blended (Okara, Zemlyak and Kalenik, 2009; Krychkovska, Belinska and Zhulinska, 2010).

Adding marinades for natural marinated semi-finished meat products based on blends of refined vegetable oils gives the products the desired consistency; allows determination of the energy value; maintains product yield and ensures the formation of taste and aroma of the product. Moreover, enrichment of blends with the enzyme bromelain will accelerate the maturation and softening of meat by a factor of $2-2.5$ (Nechaev, Traubenberg and Kochetkova, 2007).

The goal of this research was to analyze the effect of marinade components based on blends of vegetable oils using the enzyme bromelain on the organoleptic and physicochemical parameters of natural marinated semi- finished meat products. The following specific aims were further defined: to develop recipes for pickled semi-finished products and to study the influence of marinade components on organoleptic and physicochemical parameters of marinated semi-finished products.

\section{Scientific hypothesis}

The research hypothesis was based on the assumption that marinades based on blends of vegetable oils enriched with the enzyme bromelain can have a positive effect on the organoleptic and physicochemical parameters of semifinished products. The objects of the study were marinades based on vegetable oils: rapeseed, blend, sunflower:rapeseed (70:30) and blend, sunflower:olive $(80: 20)$. According to the results, it is stated that semifinished products using a marinade based on pure rapeseed oil and a blend of sunflower (70\%): rapeseed (30\%) have the best organoleptic characteristics. It is proved that the use of marinades based on blends of vegetable oils reduces the amount of moisture in the product and increases the fat content, which affects the shelf life of the product.

\section{MATERIAL AND METHODOLOGY \\ Samples}

In this article, 8 samples were examined: 4 samples using pork and 4 samples from beef. Sample 1 - pork without marinade. Sample 2 - pork with a marinade based on rapeseed oil. Sample 3 - pork with a marinade based on a blend of oils (sunflower: rapeseed $=70: 30$ ). Sample 4 pork with a marinade based on a blend of oils (sunflower: olive $=80: 20$ ). Sample 5 - beef without marinade. Sample 6 - beef with a marinade based on rapeseed oil. Sample 7 beef with a marinade based on a blend of oils (sunflower: rapeseed $=70: 30$ ). Sample 8 - beef with a marinade based on a blend of oils (sunflower: olive $=80: 20$ ).

\section{Chemicals}

To determine the protein content in the prepared samples using the following chemical reagents:

Sulfuric acid $\mathrm{H}_{2} \mathrm{SO}_{4}$, (Inter-Synthesis Limited, Liability Company, Ukraine, chemically pure for analysis).

Copper sulfate catalyst $\mathrm{CuSO}_{4}$, (Inter-Synthesis, Limited Liability Company, Ukraine, chemically pure for analysis). Inorganic sulfuric acid salt $\mathrm{Na}_{2} \mathrm{SO}_{4}$, (Inter-Synthesis, Limited Liability Company, Ukraine, chemically pure for analysis).

Sodium hydroxide NaOH, (Inter-Synthesis, Limited Liability Company, Ukraine, chemically pure for analysis).

Boric acid $\mathrm{H}_{3} \mathrm{BO}_{3}$, (Inter-Synthesis, Limited Liability Company, Ukraine, chemically pure for analysis).

Petroleum ether was used to determine the fat content in the prepared samples.

Animals and Biological Material:

We used beef grade II and pork grade II, with a high content of connective tissue.

\section{Instruments}

The following tool was used to determine the moisture content in the prepared samples:

Analytical balance (Radwag AS 220/C, (Inter-Synthesis, Limited Liability Company, Ukraine).

Drying cabinet SNOL 58/350, (Inter-Synthesis, Limited Liability Company, Ukraine). 
Boxes aluminum laboratory, (Inter-Synthesis, Limited Liability Company, Ukraine).

Desiccator without tap 2-180, (Inter-Synthesis, Limited Liability Company, Ukraine).

To determine the protein content in the prepared samples used the following equipment:

Analytical balance Radwag AS 220/C, (Inter-Synthesis, Limited Liability Company, Ukraine).

Drying cabinet SNOL 58/350, (Inter-Synthesis, Limited Liability Company, Ukraine).

Boxes (aluminum laboratory, (Inter-Synthesis, Limited Liability Company, Ukraine).

Desiccator without tap 2-180, (Inter-Synthesis, Limited

Liability Company, Ukraine).

Velp mineralizer DKL8, (Inter-Synthesis, Limited Liability Company, Ukraine).

Distillation apparatus UDK 129, (Inter-Synthesis, Limited Liability Company, Ukraine).

Folded burette with tap Class A 25 mL-0.1, (InterSynthesis, Limited Liability Company, Ukraine).

The fat content in the prepared samples was determined on a Soxhlet apparatus, as well as a drying cabinet, boxes, desiccator, paper bags made of filter paper.

To determine the ash in the samples, the following equipment was used:

Analytical balance Radwag AS 220/C, (Inter-Synthesis, Limited Liability Company, Ukraine).

Porcelain crucible tongs No2, (Inter-Synthesis, Limited Liability Company, Ukraine).

Desiccator without tap 2-180, (Inter-Synthesis, Limited Liability Company, Ukraine).

Laboratory Methods

The authors used the following laboratory research methods:

DSTU 4823.2 (2007) - Meat products. Organoleptic evaluation of quality indicators.

DSTU ISO 1442 (2005) - Meat and meat products.

Moisture content method (control method).

DSTU ISO 937 (2005) - Meat and meat products. Determination of nitrogen content (control method).

DSTU ISO 1443 (2005) - Meat and meat products.

Method for determination of total fat content.

DSTU ISO 936 (2008) - Meat and meat products. Method for determining the mass fraction of total ash.

Description of the Experiment

The main purpose of the presented experiment is to determine the effect of marinades based on blends of vegetable oils enriched with the enzyme bromelain on the physicochemical and organoleptic characteristics of natural marinated meat semi-finished products. The content of moisture, protein, fat, and ash, moisture-holding, capacity, as well as organoleptic parameters were determined: appearance, sectional view, color, taste, aroma, consistency, and juiciness.

Number of samples analyzed: For research, 8 samples were prepared, 4 samples using pork, and 4 samples from beef.

Number of repeated analyses: All measurements of instrument readings were performed 10 times.

Number of experiment replication: The number of repetitions of each experiment to determine one value was also 10 times.

\section{Statistical Analysis}

Mathematical and statistical processing of experimental data was carried out in determining the criteria of Cochran's $\mathrm{C}$ test, Fisher, and Student's $t$-test. The accuracy of the data was determined using the Cochrane criterion, and the adequacy of the mathematical model was checked using the Fisher and Student criteria. Statistical processing was performed in Microsoft Excel 2016 values were estimated using mean and standard deviations and subsequently evaluated in the statistical program XL Stat. In hypothesis testing, if the $p$-value is lower than the significant level, in the case of XL Stat software by Addinsoft (version 2019.3.2), it is 0.05, the null hypothesis was rejected and the alternative hypothesis was confirmed.

\section{RESULTS AND DISCUSSION}

Traditionally, marinated semi-finished products are made from the tender parts of the carcass, which have a significant amount of muscle protein and a small amount of fat. The scapular part of the carcass, which has a high content of connective tissue, was selected for the study. Similar scientific researches are described in works (Benzik et al., 2020; Zhumanova et al., 2018; Keniiz et al., 2019).

To reduce the toughness of the meat, we add the enzyme bromelain to the marinade, which can hydrolyze connective tissue proteins such as collagen and elastin. Scientific studies (Yang et al., 2018; Doneva et al., 2018; Cai et al., 2018) describe similar studies using other enzymes, which in our opinion are not rational to use due to their high cost. As a result, we can obtain a tender, juicy product from tough meat that is easily digested by the body. Moreover, the use of vegetable blends will retain moisture in the product during heat treatment, as well as increase product yield. In scientific works (Park et al., 2019; Shin et al., 2019; Lopacka, Póltorak and Wierzbicka, 2016; Erdaw et al., 2016) conducted more in-depth research on the use of various enzymes and their effects on the physicochemical properties of raw meat.

Recipes for natural marinated meat products differ based on marinades. In scientific works (Nesterenko et al., 2017; Jinap et al., 2018; Wang et al., 2018) research and recipes of various marinades, both for meat raw materials and for various kinds of seafood are carried out. It should be noted that when using different types of marinades there was a change in the organoleptic properties of the finished product. Due to the addition of marinade, there is a decrease in the amount of basic raw materials compared with the control sample, which does not include marinade. This will save significant funds in the manufacturing of the product (Table 1, Table 2). Recipes for marinades are given in the patents of Ukraine for the utility model "Marinade based on vegetable oils" No 134474, No 134475, No 134476 (Shtonda and Semeniuk, 2019a; Shtonda and Semeniuk, 2019b; Shtonda and Semeniuk, 2019c).

Scientific research (Semeniuk and Shtonda, 2021) describe influence of fatty acid structure of vegetable oils on physical and chemical indicators of quality of blends vegetable oils.

Preparation of the marinade based on blends of vegetable oils and the introduction of the enzyme bromelain increased the product yield and improved the digestibility compared with control samples. 
Organoleptic evaluation of natural marinated semifinished meat products was conducted in the form of a tasting, which was attended by teachers and students of the Department of Meat, Fish and Seafood Technology of the National University of Life and Environmental Sciences of Ukraine. The following indicators were determined: appearance, sectional view, color, aroma, taste, consistency, and juiciness. The organoleptic evaluation was performed and scored on a five-point scale (Figure 1, Figure 2).

As a result of the organoleptic evaluation of marinated semi-finished pork products, it was found that the best indicators were found in samples treated with marinades based on pure rapeseed oil (sample No1) and a mixture of rapeseed (30\%) and sunflower (70\%) oil (sample No2). These samples possessed a delicate, juicy consistency, a clear appearance in the cut, and a pleasant taste and aroma. Scientific articles (Suárez et al., 2021; Trabelsi et al., 2018; Obajuluwa et al., 2020; Jung et al., 2018) presents several experimental studies concerning the use of marinades based on olive, corn, soybean, and peanut oils in
The organoleptic evaluation of marinated semi-finished beef products showed that the best base for the marinade was a mixture of rapeseed (30\%) and sunflower (70\%) oils (sample No6).

Chemical composition is one of the main indicators that affects the quality of the product. Chemical composition studies were performed on the first day of storage of natural marinated semi-finished meat products (Table 3). Scientific papers (Ivankin et al., 2020; Lorenzo et al., 2018; Reis et al., 2018; Smetanska et al., 2021) describe a number of experimental studies on the chemical composition of natural marinated meat semi-finished products, but they were conducted on the third, fifth and tenth days of storage.

The results of the study of the chemical composition show that for marinated semi-finished products in comparison with the control sample there is a decrease in the amount of moisture and an increase in the amount of fat in the product due to the presence of oil in the marinade. This helps to increase the shelf life of the product.

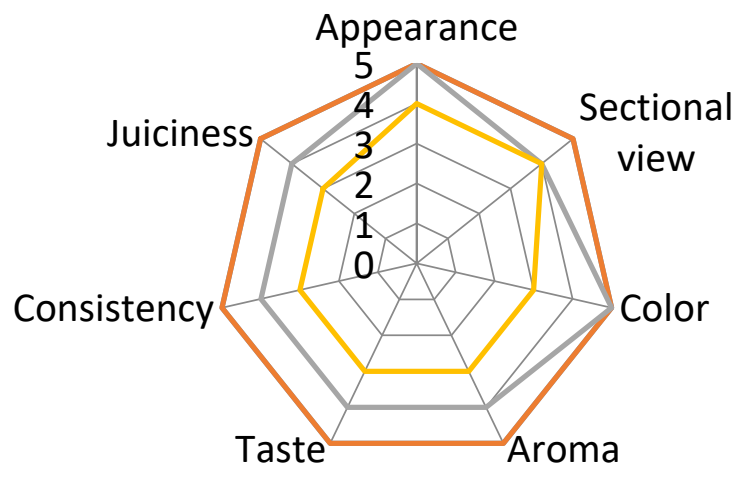

Figure 1 Organoleptic evaluation of marinated semi-finished pork products.

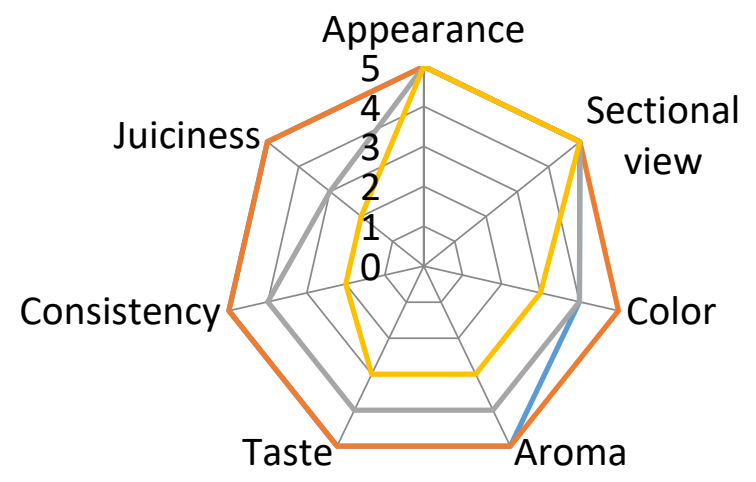

Figure 2 Organoleptic evaluation of marinated semi-finished beef.

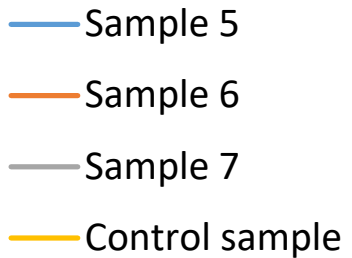

various combinations and ratios. We performed several experiments and found that some samples did not have a juicy consistency and an unpleasant taste and aroma (a mixture of corn and soybean oils). 


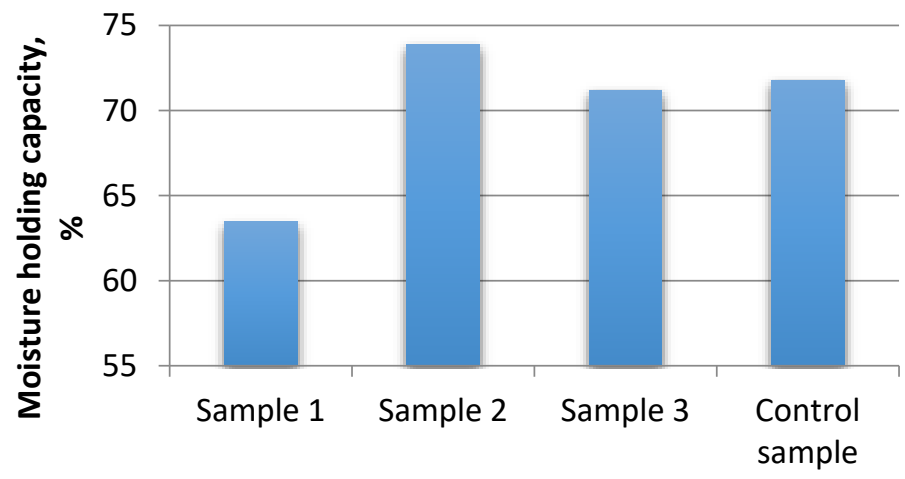

- Semi-finished pork

Figure 3 Moisture-holding capacity of marinated semi-finished pork products.

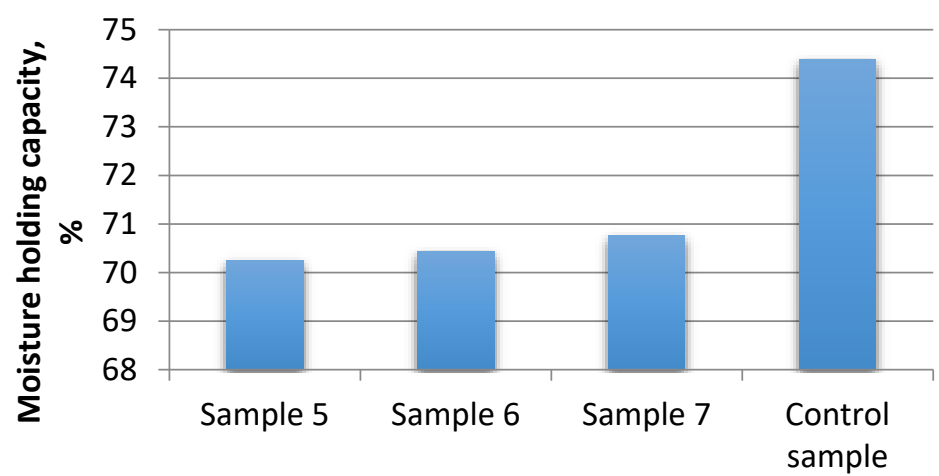

Semi-finished beef

Figure 4 Moisture-holding capacity of marinated semi-finished beef products.

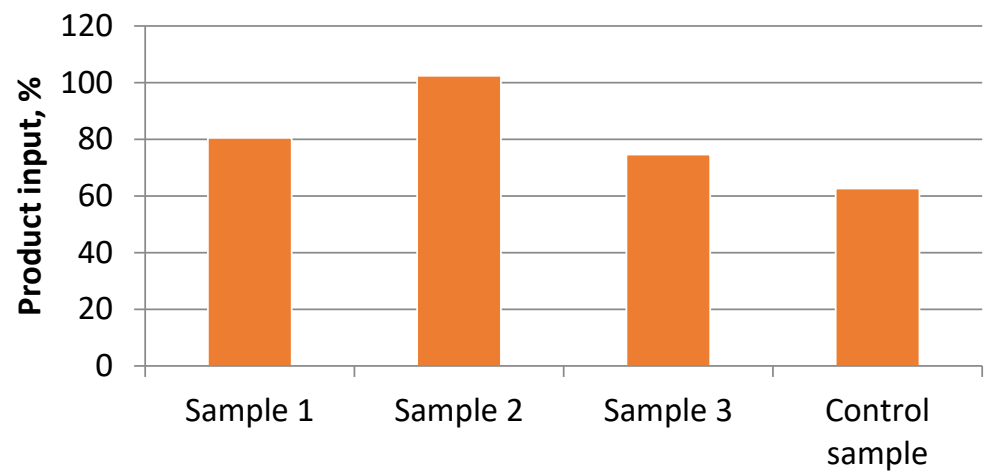

- Semi-finished pork

Figure 5 Yield of marinated semi-finished pork.

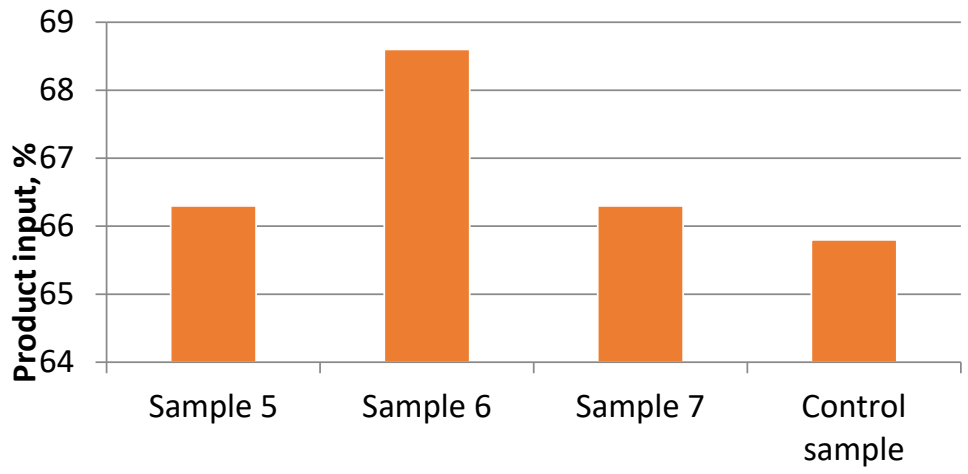

Semi-finished beef

Figure 6 Yield of marinated semi-finished products from beef. 
A decrease in the amount of free moisture in the product leads to an increase in the moisture-binding capacity (Shtonda and Semeniuk, 2018; Makarenko et al., 2021) and, accordingly, to a decrease in the moisture-holding capacity (Figure 3, Figure 4).

The use of vegetable oil blends in the marinade not only ensures the balance of the product in terms of fatty acid composition but also increases the yield of the product (Figure 5, Figure 6).

It was found that the product yield after heat treatment increased by $19.17 \%$ - $63.58 \%$ for semi-finished pork products relative to the control sample and by $0.76 \%$ 4.25\% for beef semi-finished products, compared with the control sample.

\section{CONCLUSION}

Six recipes for marinated semi-finished products have been developed: three recipes using pork and three recipes using beef. As a result of the research, it was found that semi-finished products using a marinade based on a pure rapeseed oil and sunflower blend (70\%): rapeseed (30\%) have the best organoleptic characteristics. We have shown that the use of marinades based on blends of vegetable oils leads to a decrease in the amount of moisture in the product and an increase in fat content, which affects the shelf life of the product. The possibility of reducing the duration of production of natural marinated semi-finished meat products by a factor of 5 due to the introduction of enzyme preparations into the marinade has been established experimentally.

\section{REFERENCES}

Belinskaya, A. P. 2011. Technology of blended oil of increased biological value: dissertation theses. Kharkiv, Ukraine, 230 p.

Benzik, I., Brazhnaia, I., Bogdan, E., Ershov, A. 2020. Effects of the Marinating Process on the Quality of the Domesticated Reindeer (Rangifer Tarandus) By-products. KnE Life Sciences, $\quad$ p. 686-695. https://doi.org/10.18502/kls.v5i1.6151

Brenna, J. T. 2002. Efficiency of conversion of $\alpha$-linolenic acid to long chain n-3 fatty acids in man. Current Opinion in Clinical Nutrition \& Metabolic Care, vol. 5, no. 2, p. 127-132. https://doi.org/10.1097/00075197-200203000-00002

Cai, K., Shao, W., Chen, X., Campbell, Y. L., Nair, M. N., Suman, S. P., Schilling, M. 2018. Meat quality traits and proteome profile of woody broiler breast (pectoralis major) meat. Poultry science, vol. 97, no. 1, p. 337-346. https://doi.org/10.3382/ps/pex284

Domaretskyy, V. A., Ostapchuk, M. V. 2003. Ukrainian AI Food Technology. Kyiv, Ukraine: NUHT, 572 p. ISBN 966612-027-5.

Doneva, M., Nacheva, I., Dyankova, S., Metodieva, P., Miteva, D. 2018. Application of plant proteolytic enzymes for tenderization of rabbit meat. Biotechnology in Animal Husbandry, vol. 34, no. 2, p. 229-238. https://doi.org/10.2298/BAH1802229D

DSTU 4823.2. 2007. Meat products. Organoleptic evaluation of quality indicators. Part 2. General requirements.

DSTU ISO 1442. 2005. Meat and meat products. Moisture content method (control method) (ISO 1442: 1997, IDT). With amendment.
DSTU ISO 1443. 2005. Meat and meat products. Method for determination of total fat content (ISO 1443: 1973, IDT). With amendment.

DSTU ISO 936. 2008. Meat and meat products. Method for determining the mass fraction of total ash (ISO 936: 1998, IDT).

DSTU ISO 937. 2005. Meat and meat products. Determination of nitrogen content (control method) (ISO 9371978, IDT).

Erdaw, M. M., Perez-Maldonado, R. A., Bhuiyan, M., Iji, P. A. 2016. Physicochemical properties and enzymatic in vitro nutrient digestibility of full-fat soybean meal. J. Food Agric. Environ., vol. 14, p. 85-91.

Gubsky, Y. I. 2000. Biological Chemistry. Kyiv-Ternopil, Ukraine : Ukrmedkniga, 508 p. ISBN 966-7364-41-0.

Ivankin, A., Vostrikova, N., Krasulya, O., Kazakova, E., Kulikovskii, A., Knyazeva, A. 2020. The formation of flavoring characteristics of meat products by changing the chemical composition of food compositions. Theory and practice of meat processing, vol. 5, no. 4, p. 4-12. https://doi.org/10.21323/2414-438X-2020-5-4-4-12

Jinap, S., Hasnol, N. D. S., Sanny, M., Jahurul, M. H. A. 2018. Effect of organic acid ingredients in marinades containing different types of sugar on the formation of heterocyclic amines in grilled chicken. Food Control, vol. 84, p. 478-484. https://doi.org/10.1016/j.foodcont.2017.08.025

Jung, Y., Rupert, C. L., Chapman, B., Porto Fett, A. C., Luchansky, J. B. 2018. Assessment of microbiological safety and quality of marinades used to treat beef and that were collected over a 12-month period from specialty retailers near Raleigh, North Carolina. Journal of food protection, vol. 81, no. 3, p. 490-496. https://doi.org/10.4315/0362-028X.JFP-17$\underline{396}$

Keniiz, N., Nesterenko, A., Omarov, R., Konik, N., Rysmukhambetova, G. 2019. Study of the influence of cryoprotectants on the preservation of the technological properties of frozen test semi-finished products. Research Journal of Pharmaceutical, Biological and Chemical Sciences, vol. 10, no. 1, p. 1559-1566.

Koh, G. 2005. Production and formulations of meat products. Meat gastronomy: St. Petersburg, Russia : Profession, 656 p. ISBN 5-93913-074-7:2000.

Kolyanovska, L. M., Palamarchuk, I. P., Sukhenko, Y., Mussabekova, A., Bissarinov, B., Popiel, P., Mushtruk, M. M., Sukhenkko, V., Vasuliev, V., Semko, T., Tyshchenko, L. 2019. Mathematical modeling of the extraction process of oilcontaining raw materials with pulsed intensification of heat of mass transfer. Proceedings of SPIE - The International Society for Optical Engineering, $25 \quad$ p. https://doi.org/10.1117/12.2522354

Krychkovska, L., Belinska, A., Zhulinska, O. 2010. Functional components in blended vegetable oils with carotene. Good and markets, vol. 2, p. 97-103.

Łopacka, J., Półtorak, A., Wierzbicka, A. 2016. Effect of MAP, vacuum skin-pack and combined packaging methods on physicochemical properties of beef steaks stored up to 12 days. Meat science, vol. 119, p. 147-153. https://doi.org/10.1016/j.meatsci.2016.04.034

Lorenzo, J. M., Munekata, P. E., Sant'Ana, A. S., Carvalho, R. B., Barba, F. J., Toldrá, F., Trindade, M. A. 2018. Main characteristics of peanut skin and its role for the preservation of meat products. Trends in Food Science \& Technology, vol. 77, p. 1-10. https://doi.org/10.1016/j.tifs.2018.04.007

Makarenko, A., Mushtruk, M., Rudyk-Leuska, N., Kononenko, I., Shevchenko, P., Khyzhniak, M., Martseniuk, N., Glebova, J., Bazaeva, A., Khalturin, M. 2021. The study of 
the variability of morphobiological indicators of different size and weight groups of hybrid silver carp (Hypophthalmichthys spp.) as a promising direction of development of the fish processing industry. Potravinarstvo Slovak Journal of Food Sciences, vol. 15, no. 1, p. 181-191. https://doi.org/10.5219/1537

Mushtruk, M., Gudzenko, M., Palamarchuk, I., Vasyliv, V., Slobodyanyuk, N., Kuts, A., Nychyk, O., Salavor, O., Bober, A. 2020a. Mathematical modeling of the oil extrusion process with pre-grinding of raw materials in a twin-screw extruder. Potravinarstvo Slovak Journal of Food Sciences, vol. 14, no. 1, p. 937-944. https://doi.org/10.5219/1436

Mushtruk, M., Vasyliv, V., Slobodaniuk, N., Mukoid, R., Deviatko, O. 2020b. Improvement of the Production Technology of Liquid Biofuel from Technical Fats and Oils. In Ivanov, V., Trojanowska, J., Machado, J., Liaposhchenko, O., Zajac, J., Pavlenko, I., Edl, M., Perakovic, D. Advances in Design, Simulation and Manufacturing III. Switzerland : Springer International Publishing, p. 377-386. ISBN 21954364-21954356. https://doi.org/10.1007/978-3-03050491-5_36

Nechaev, A. P., Traubenberg, S. E., Kochetkova, A. A. 2007. Food Chemistry: Textbook. $4^{\text {nd }}$ ed. SPb : Giord, 640 p. ISBN 5-98879-011-9.

Nesterenko, A., Koshchaev, A., Keniiz, N., Shhalahov, D. S.,Vilts, K. R. F. 2017. Development of device for electromagnetic treatment of raw meat and starter cultures. Research Journal of Pharmaceutical, Biological and Chemical Sciences, vol. 8, no. 1, p. 1080-1085.

Obajuluwa, O., Sanwo, K., Akinola, O., Sobukola, O., Adeola, A., Faloye, O. 2020. Effect of unconventional marinades on beef quality. Nigerian Journal of Animal Production, vol. 47, no.1, p. 90-99. https://doi.org/10.51791/njap.v47i1.193

Okara, A. I., Zemlyak, K. G., Kalenik, T. K. 2009. Management of fatty acid composition and consumer properties of vegetable oils-mixtures by optimization of formulations. Oil and Fat Industry, vol. 2, p. 8-10. (In Russia).

Park, H. , Lee, C., Sim, E., Kim, H., Jeon, Y., Kwak, J., Woo, K. 2019. Physicochemical properties of commercial beef porridge in Korea. The Korean Journal of Food And Nutrition, vol. 32, no. 3, p. 226-235.

Proust, F., Lucas, M., Deawailly, É. 2014. Fatty acid profiles among the Inuit of Nunavi: Current status and temporal change. Prostaglandins, Leukotrienes and Essential Fatty Acids, vol. $\quad 90, \quad$ p. $159-167$. https://doi.org/10.1016/j.plefa.2014.02.001.

Reis, M. M., Van Beers, R., Al-Sarayreh, M., Shorten, P., Yan, W. Q., Saeys, W., Craigie, C. 2018. Chemometrics and hyperspectral imaging applied to assessment of chemical, textural and structural characteristics of meat. Meat science, vol. 144 ,

https://doi.org/10.1016/j.meatsci.2018.05.020

Semeniuk, K. M., Shtonda, O. A., 2021. Peculiarities of influence of fatty acid composition of oils on physical and chemical parameters of quality of blends of vegetable oils 2021. Herald of Lviv University of Trade and Economics. Technical Sciences, vol. 25, p. 106-110

Shin, H., Kim, H. T., Choi, M. J., Ko, E. Y. 2019. Effects of bromelain and double emulsion on the physicochemical properties of pork loin. Food science of animal resources, vol. 39, no. 6, p. 888. https://doi.org/10.5851/kosfa.2019.e70

Shtonda, O. A., Semeniuk, K. M. 2019a. Office of Economic Development and Trade of Ukraine. Marinade based on vegetable oils. Patent owner: Shtonda, O.A., Semeniuk, K.M. Int.Cl.A23L13/70. Ukraine. Patent no. 134474, 2019a-05-27.
Shtonda, O. A., Semeniuk, K. M. 2019b. Office of Economic Development and Trade of Ukraine. Marinade based on vegetable oils. Patent owner: Shtonda, O. A., Semeniuk, K. M. Int.Cl.A23L13/70. Ukraine. Patent no. 134475, 2019b-05-27.

Shtonda, O. A., Semeniuk, K. M. 2019c. Office of Economic Development and Trade of Ukraine. Marinade based on vegetable oils. Patent owner: Shtonda, O. A., Semeniuk, K. M. Int.Cl.A23L13/70. Ukraine. Patent no. 134476, 2019c-05-27.

Shtonda, O. A., Semeniuk, K. M., 2018. Changing the technological characteristics of natural semi-finished meat products under the action of marinades on the basis of vegetable oils 2018. Newest Technologies. Collection of scientific works, vol. 3, no. 7, p. 110-116. https://doi.org/10.31180/2524-0102/2018.3.07.13

Smetanska, I., Tonkha, O., Patyka, T., Hunaefi, D., Mamdouh, D., Patyka, M., Bukin, A., Mushtruk, M., Slobodyanyuk, N., Omelian, A. 2021. The influence of yeast extract and jasmonic acid on phenolic acids content of in vitro hairy root cultures of Orthosiphon aristatus. Potravinarstvo Slovak Journal of Food Sciences, vol. 15, no. 1, p. 1-8. https://doi.org/10.5219/1508

Suárez, M., Gual-Grau, A., Ávila-Román, J., Torres-Fuentes, C., Mulero, M., Aragonès, G., Muguerza, B. 2021. Oils and Oilseeds in the Nutraceutical and Functional Food Industries. Oil and Oilseed Processing: Opportunities and Challenges, p. 219-243. https://doi.org/10.1002/9781119575313.ch11

Sukhenko, Y., Mushtruk, M., Vasyliv, V., Sukhenko, V., Dudchenko, V. 2020. Production of pumpkin pectin paste. Lecture Notes in Mechanical Engineering, p. 805-812. https://doi.org/10.1007/978-3-030-22365-6_80

Sukhenko, Y., Sukhenko, V., Mushtruk, M., Vasuliv, V., Boyko, Y. 2017. Changing the quality of ground meat for sausage products in the process of grinding. Eastern European Journal of Enterprise Technologies., vol. 4, no. 11, p. 56-63. https://doi.org/10.15587/1729-4061.2017.108876

Trabelsi, N., Marotta, S. M., Giarratana, F., Taamali, A., Zarrouk, M., Ziino, G., Giuffrida, A. 2018. Use of Tunisian flavored olive oil as anisakicidal agent in industrial anchovy marinating process. Journal of the Science of Food and Agriculture, vol. 98, no. 9, p. 3446-3451. https://doi.org/10.1002/jsfa.8857

Tvrzická, E., Staňková, B., Vecka, M., Žák, A.2009. Fatty acids 1. Occurrence and biological significance. Casopis lekaru ceskych, vol. 148, p. 16-24. (In Czech).

Tyshchenko, L., Shtonda, O., Pylypchuk, O., Shakhvorostova, V. 2019. Poultry fats. Features of the composition and characteristics of stability to oxidation 2019. Food Science and Technology, vol. 13, no. 4, p. 69-75. https://doi.org/10.15673/fst.v13i4.1569 (In Ukraine)

Wang, C., Xie, Y., Qi, J., Yu, Y., Bai, Y., Dai, C., Zhou, G. 2018. Effect of tea marinades on the formation of polycyclic aromatic hydrocarbons in charcoal-grilled chicken wings. Food Control, vol. 93, p. 325-333. https://doi.org/10.1016/j.foodcont.2017.12.010

Yang, Y., Sun, Y., Pan, D., Wang, Y., Cao, J. 2018. Effects of high pressure treatment on lipolysis-oxidation and volatiles of marinated pork meat in soy sauce. Meat science, vol. 145, p. 186-194. https://doi.org/10.1016/j.meatsci.2018.06.036

Zhumanova, G., Rebezov, M., Assenova, B., Okuskhanova, E. 2018. Prospects of using poultry by-products in the technology of chopped semi-finished products. International Journal of Engineering and Technology (UAE), vol. 7, no. 34, p. 495-498. https://doi.org/10.14419/ijet.v7i3.34.19367 


\section{Funds:}

This research received no external funding.

\section{Conflict of Interest:}

The authors declare no conflict of interest.

\section{Ethical Statement:}

This article does not contain any studies that would require an ethical statement.

\section{Contact Address:}

*Oksana Shtonda, National University of Life and Environmental Sciences of Ukraine, Faculty of Food Technology and Quality Management of Agricultural Products, Department of Meat, Fish and Seafoods, Heroiv Oborony Str., 15, Kyiv, 03040, Ukraine, Tel.: +38(050)1406657,

Email: oasht@ukr.net

ORCID: https://orcid.org/0000-0002-7085-6133
Kateryna Semeniuk, National University of Life and Environmental Sciences of Ukraine, Faculty of Food Technology and Quality Management of Agricultural Products, Department of Meat, Fish and Seafoods, Heroiv Oborony Str., 15, Kyiv, 03040, Ukraine, Tel.: +38(093)1077003,

Email: kataysemenuk@ukr.net

ORCID: https://orcid.org/0000-0003-0934-5155

Corresponding author: * 